\title{
Chronicle
}

\section{Anniversary of Marianna Sankiewicz-Budzynski}

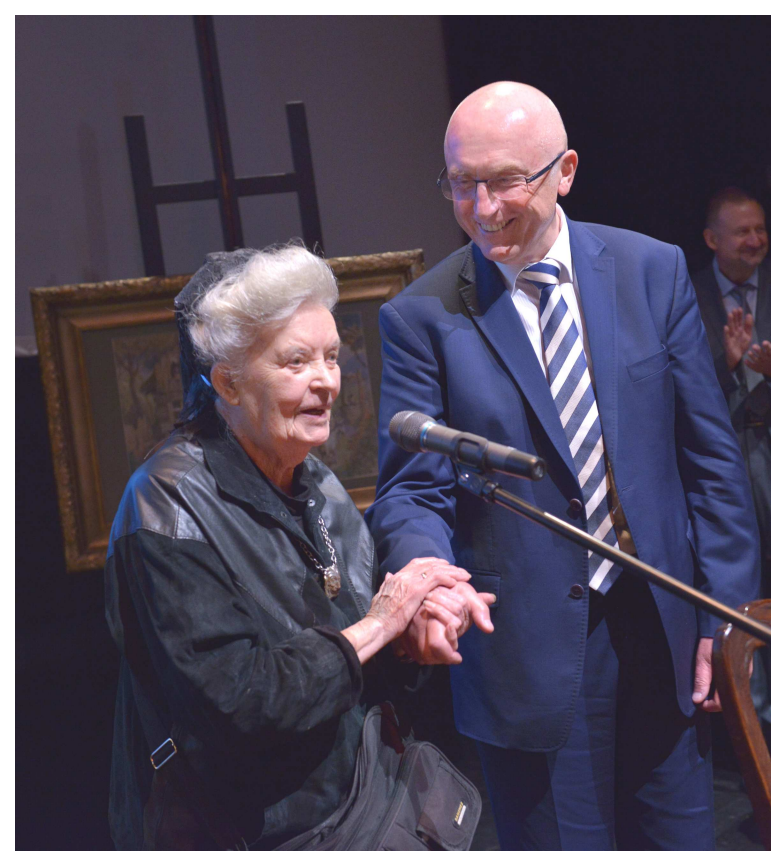

(photo: K. Krzempek)

On September 23, 2016, we celebrated the 95 anniversary of Marianna Sankiewicz-Budzynski (more information at http://mariannasankiewicz.pl/).

Marianna Sankiewicz-Budzynski was born in Przerośl near Suwałki on September 26, 1921. During World War II she was deported to forced labor. After the war she settled in Gdańsk, which is her living place up to today. After returning to Polish, in February 1945, she started working at the Polish Radio in Warsaw, and then in the Department of Polish Radio in Gdańsk and began studies at the Faculty of Electrical Engineering at the Technical University of Gdańsk, where in 1950 she received a master's degree in engineering. In 1953 she started her scientific career as an assistant in the Department of Radiobroadcast Equipment of the Department of Communications of the Technical University. Then she lectured at the Department of Radio Communications, where she organized a workshop of electrophony and in 1968 she led to the creation of the Electrophony Department, later called Sound Engineering. In 1968, based on the work "Resistance resistive negative-stable"
Marianna Sankiewicz obtained her Ph.D. degree under supervisor of the legendary Polish professor Janusz Groszkowski. Since 1970 she worked as an assistant professor. For 17 years she was vice-dean for Education Faculties of Communications and Electronics, and then at the Faculty of Electronics, Telecommunications and Informatics she worked until her retirement in 1992. Also to 1992 she held an employment at Polish Radio. She led the training of professionalists in Technical and Program Centers of Northern Region for Polish Radio and Television. She co-organized (with her husband and scientific collaborator Gustaw Budzyński) at the Faculty the new specialization called Sound Engineering that was unique on a national scale, which proved to be fruitful in didactic and research areas. In 1981, as the first woman in the post-war history of Gdańsk University of Technology she was elected for vice-rector for education. For his approach to the process of education it was highly appreciated by the students. In the scientific work she specialized in issues related to electronics and electroacoustics. 
She was and still is a member of the international scientific societies. It is worth emphasizing its activity in the world accompanied by sound engineers, i.e. The Audio Engineering Society (AES). In 1991, during the Fourth Symposium on Sound Engineering and Mastering in Gdańsk she organized the Polish Section of the Audio Engineering Society, for which she was the first president. Marianna Sankiewicz was elected to the position of Vice President of the AES, Central European Region, and during her term of office held she led to creation of new Sections of AES (Lithuania, Russia, Belarus, Ukraine, Israel), as well as new sections in Poland. For her contribution to the development of the Audio Engineering Society she was awarded the "Citation" and in 2005 for achievements in the field of education received the honorary title "AES Fellow". She was also a member of the Committee of Acoustics of the Polish Academy of Sciences and the Polish Acoustical Society. In 2011, President Bronislaw Komorowski awarded her the Commander's Cross of the Order of the Rebirth of Poland.

Polish Section of Audioengineering Society 